\title{
Kebijakan Pembelajaran Terpadu dalam Meningkatkan Minat Konsumen Pendidikan
}

\author{
Fatkuroji \\ IAIN Walisongo Semarang
}

\begin{abstract}
Quality educational services to the challenge of pen-education development in Indonesia. Quality education will produce quality human resources as well. Impact many institutions offer learning system integration. It becomes a policy in response to the needs of consumers in an era of globalization and technology era. Learning is useful in solving the problems facing educational institutions and consumer needs. Learning is expected to meet the complexities of the human personality as the integrity of national education goals. Learning system is expected to improve the intellectual and spiritual competence of learners. This policy should be used as a basis for the development of education in this country.
\end{abstract}

Keywords: $\quad$ integrated learning, the quality, the consumer.

\begin{abstract}
Abstrak
Pelayanan pendidikan berkualitas menjadi tantangan pengembangan pendidikan di Indonesia. Pendidikan yang berkualitas akan menghasilkan sumber daya manusia yang berkualitas pula. Imbasnya banyak lembaga pendidikan menawarkan sistem pembelajaran yang integrasi. Hal ini menjadi kebijakan dalam merespons kebutuhan konsumen di era globalisasi dan era teknologi. Pembelajaran ini berguna dalam memecahkan masalah yang dihadapi lembaga pendidikan dan kebutuhan konsumen. Pembelajaran ini diharapkan menjawab kompleksitas keutuhan kepribadian manusia sebagai tujuan pendidikan nasional. Sistem pembelajaran diharapkan dapat meningkatkan kompetensi intelektual dan spiritual peserta didik. Kebijakan inilah yang harus dijadikan dasar pengembangan pendidikan di negeri ini.
\end{abstract}

Kata kunci: pembelajaran terpadu, mutu, konsumen. 


\section{A. Pendahuluan}

Pendidikan adalah investasi dalam pengembangan sumber daya manusia, dan pendidikan merupakan bagian penting dari proses pembangunan nasional dan ikut menentukan pertumbuhan ekonomi suatu negara di mana peningkatan kecakapan dan kemampuan diyakini sebagai faktor pendukung upaya manusia dalam mengarungi kehidupan yang penuh dengan ketidakpastian. Dalam kerangka inilah pendidikan dipandang sebagai kebutuhan yang mendasar bagi masyarakat yang ingin maju. Pendidikan memberikan kontribusi yang sangat besar terhadap kemajuan suatu bangsa, dan merupakan wahana dalam menerjemahkan pesan-pesan konstitusi serta sarana dalam membangun watak bangsa. ${ }^{1}$

Peningkatan kualitas pendidikan menuntut manajemen pembelajaran yang lebih baik sebagai salah satu strategi untuk mendayagunakan semua komponen pendidikan dalam upaya pencapaian tujuan yang direncanakan. Hasil penelitian Balitbangdikbud (1991) menunjukkan bahwa manajemen pembelajaran di sekolah merupakan salah satu faktor yang mempengaruhi kualitas pendidikan. Manajemen pembelajaran sekolah secara langsung akan mempengaruhi dan menentukan efektif tidaknya kurikulum, berbagai peralatan belajar, waktu mengajar dan proses pembelajaran.

Tantangan pengembangan pendidikan nasional saat ini adalah pelayanan pendidikan berkualitas yang dapat diakses sebanyakbanyaknya oleh rakyat Indonesia. Pengembangan pendidikan nasional yang berkualitas akan menghasilkan sumber daya manusia yang berkualitas pula. Semakin banyak rakyat yang mampu mengakses pendidikan berkualitas, diharapkan terjadi peningkatan kualitas sumber daya manusia Indonesia secara signifikan. $^{2}$ Pada umumnya, dalam sebuah negara ketersediaan pendidikan yang berkualitas akan ekuivalen dengan kualitas sumber daya manusianya. Keadaan sumberdaya manusia yang berkualitas akan ekuivalen pula dengan kesejahteraan rakyatnya. Jadi, cita-cita kesejahteraan rakyat Indonesia harus dimulai dari

${ }^{1}$ Mulyasa, Manajemen Berbasis Sekolah, (konsep, strategi dan Implementasi, ( Bandung: Remaja Rosdakarya, 2002), hlm.4.

2 Ali Imron, Kebijakan Pendidikan di Indonesia Proses, Produk, dan Masa Depannya, (Jakarta: Bumi Aksara, 1996), hlm. 60. 
kesungguhan dalam pengembangan pendidikan nasional yang berkualitas.

Salah satu tawaran yang dikembangkan oleh beberapa lembaga pendidikan saat ini adalah pembelajaran integrasi atau terpadu. Melalui pembelajaran terpadu ini diharapkan menjawab kompleksitas keutuhan kepribadian manusia sebagaimana yang telah dideskripsikan dalam tujuan pendidikan nasional. Menurut Ali (Prof. Dr. H. Mohammad Ali, M.A. Dirjen Pendidikan Islam Kementrian Agama RI) pembelajaran terpadu diharapkan mampu mewujudkan model pengembangan kompetensi sains dan teknologi serta pembinaan moral siswa secara bersama-sama. ${ }^{3}$

Adapun yang telah dikembangkan oleh lembaga pendidikan SDIT yang di pelopori oleh SDIT Bina Amal dan SDI Al-Azhar 29 merupakan kebijakan dalam merespons kebutuhan konsumen, dan sistem pembelajaran terpadu hendaknya bukan sekedar wacana menuju spiritual sains, tetapi menjadi fakta yang meningkatkan kompetensi intelektual dan spiritual peserta didik. Namun demikian, pada dataran implementatif pembelajaran terpadu sains dan agama tidak mudah diwujudkan. Persoalan utama dalam melangsungkan pembelajaran terpadu sains dan agama adalah persoalan terpadu itu sendiri. ${ }^{4}$

Sebagai contoh Sekolah Dasar Islam Terpadu (SDIT) Bina Amal maupun SDI Al-Azar 29 meyakini bahwa pembelajaran terpadu dianggap mampu mengembangkan multipotensi manusia menjadi individu utuh (integral) beriman kepada Allah, terampil hidup dalam beragam situasi, dan bertanggung jawab secara sosial, dan harapan ini sesuai dengan Standar Nasional Pendidikan “... meningkatkan kecerdasan, pengetahuan, kepribadian, ahlak mulia dan mengikuti studi lanjut .... (No. 19 tahun 2005 pasal 26).

Berbicara mengenai minat konsumen terhadap lembaga pendidikan, banyak variabel yang mempengaruhi konsumen pendidikan dalam melakukan pembelian produk pendidikan, diantaranya yaitu model kegiatan pembelajarannya, kualitas pelayanan yang diberikan, besarnya biaya dan citra lembaga, yang dikenakan menjadi perhatian yang tidak bisa dibiarkan pimpinan lembaga pendidikan untuk meningkatkan minat konsumen dalam pendidikan. Cita rasa konsumen juga mempunyai pengaruh yang

\footnotetext{
${ }^{3}$ Republika, 01-02-2007.

${ }^{4}$ Hasil wawancara dengan kepala sekolah SDI Al-Azhar, 2012.
} 
cukup besar atas keinginan konsumen untuk membeli produk pendidikan. Oleh karena itu lembaga pendidikan harus benarbenar mengetahui kondisi selera konsumen pendidikan sekarang sehingga nantinya dalam menentukan apa yang menjadi cita rasa atau selera konsumen ini tidak mengalami kesulitan.

\section{B. Kerangka Teori}

1. Pengertian Analisis Kebijaksanaan

Analisis kebijakan adalah aktivitas menciptakan pengetahuan tentang dalam proses pembuatan kebijakan. Dalam menciptakan pengetahuan tentang proses pembuatan kebijakan perlu diteliti sebab, akibat, dan kinerja kebijakan dan program publik. Secara etimologis, kebijaksanaan merupakan terjemahan dari kata policy, yang oleh Supardi dibagi menjadi tiga kata yaitu: pilitic, policy dan polici. ${ }^{5}$

Adapun kebijaksanaan pendidikan merupakan terjemahan dari education policy. Education policy sendiri merupakan penggabungan antara kata education dan policy. Untuk lebih jelasnya di bawah ini ada beberapa pendapat tokoh tentang analisis kebijakan, yang di antaranya adalah:

a. Anderson dalam Sucipto (1987) mendefinisikan kebijaksanaan sebagai serangkaian tindakan yang mempunyai tujuan tertentu yang mesti diikuti dan dilakukan oleh para pelakunya untuk memecahkan suatu masalah.

b. Budiharjo dalam Imron (1996) menyatakan bahwa kebijaksanaan adalah sekumpulan keputusan yang diambil oleh seseorang pelaku atau kelompok politik dalam usaha memilih tujuan-tujuan dan cara-cara untuk mencapai tujuan-tujuan tersebut. Pada prinsipnya, pihak yang membuat kebijaksanaan itu mempuyai kekuasaan untuk melaksanakannya. ${ }^{6}$

Sedangkan Duncan dalam Ace Suryadi mengatakan analisa kebijakan adalah sebagai suatu disiplin ilmu sosial terapan yang menggunakan argumentasi rasional dengan menggunakan fakta-fakta untuk menjelaskan, menilai,

\footnotetext{
${ }^{5}$ Imron, Kebijakan Pendidikan ..., hlm.13.

${ }^{6}$ Imron, Kebijakan Pendidikan ..., hlm. 15.
} 
argumentasi nasional dengan menggunakan membuahkan pemikiran dalam rangka upaya memecahkan masalah publik.

Dari beberapa pendapat tokoh tersebut dapat disimpulkan bahwa analisis kebijakan adalah cara atau prosedur dalam menggunakan pemahaman manusia terhadap dan untuk memecahkan masalah kebijakan. Pada hakikatnya analisis kebijakan melibatkan hasil pengetahuan tentang sesuatu dalam proses kebijakan. Secara historis tujuan analisis kebijakan adalah menyediakan informasi bagi pembuat kebijakan untuk dijadikan bahan pertimbangan yang nalar guna menemukan pemecahan masalah kebijakan. $^{7}$

\section{Sejarah Perkembangan Analisis Kebijaksanaan}

Adapun sejarah perkembangan analisis kebijaksanaan ini dapat dilacak ke satu titik evolusi masyarakat di mana pengetahuan tentang dan dalam proses kebijakan secara sadar dibuat, sehingga dapat memungkinkan dilakukan pengujian secara eksplisit dan relatif terhadap kaitan antara pengetahuan dan aksi. Waktu persis kapan pengetahuan yang relevan dengan kebijakan pertama kali dihasilkan dapat diperdebatkan dan barangkali tak dapat diketahui. Akan tetapi pada umumnya mempercayai perkembangan prosedur untuk menganalisis kebijakan publik berhubungan dengan pertumbuhan peradaban yang relatif tiba-tiba dari suku atau bangsa yang memiliki kebebasan yang sangat luas dan melalui espensi serta deferensi peradaban dalam sejarah. ${ }^{8}$

Singkatnya perkembangan analisis kebijakan sebagai berikut; Evolusi analisis kebijakan umumnya telah mengikuti perubahan di dalam masyarakat. Salah satu perubahan besar di dalam masyarakat adalah tumbuhnya wilayah perkotaan di Messopotamia dan kemudian di India, Cina, dan Yunani. Pada periode abad pertengahan peradaban perkotaan menjadi lebih kompleks dengan adanya diferensiasi dan spesialisasi peran analisis kebijakan terutama permasalahan Keuangan, Perang dan Hukum. Peran transportasi utama di dalam produk pengetahuan terjadi sebagai akibat revolusi industri dan zaman pencerahan, keduanya di ikuti pertumbuhan stabilitas politik

${ }^{7}$ William N Dunn, Pengantar Analisis Kebijakan Publik, (Yogyakarta: Gajah Mada university Press, 2000), hlm. 87.

${ }^{8}$ William N Dunn, Pengantar Analisis ..., hlm. 53. 
di antara kekacauan sosial. Pada abad 20 analisis kebijakan berkembang, pertama untuk menanggapi kelesuan ekonomi dan perang, dan kemudian sebagai reaksi terhadap pemerintah yang tumbuh secara dramatis. Sesudah perang dunia kedua kita melihat kemunculan masyarakat pasca industri di mana class teknis profesional yang terdidik telah mencapai posisi yang menonjol yang tidak terduga seperti periode sebelumnya.

3. Fungsi Analisis Kebijaksanaan

Adapun fungsi analisis kebijakan dapat di kelompokkan ke dalam tiga kategori besar yaitu :

a. Fungsi Alokasi, artinya analisis kebijaksanaan perlu mengalokasikan agenda penelitian, pengembangan dan analisis kebijakan itu sendiri yang didasarkan pada kajian terhadap isu-isu kebijakan dalam tingkatan yang lebih makro dan strategis. Untuk melaksanakan fungsi penting ini analisis kebijakan harus mampu melibatkan diri di dalam, atau paling tidak mempelajari tentang sistem dan proses pembuatan kebijakan, baik dalam tingkatan suprastruktur (politis) maupun dalam tingkatan sektoral (teknis). Kajian makro ini tidak akan terlepas dari sistem-sistem lain yang menyangkut sistem ideologi, politik ekonomi, sosialbudaya, dan hankamnas karena sistem pendidikan merupakan derived demand dari sistem-sistem makro tersebut.

b. Fungsi Inquiri, artinya fungsi ini dapat dilakukan jika seluruh atau sebagian agenda penelitian dan pengembangan sudah dilaksanakan dan sudah mencapai hasil-hasilnya. Sebelum fungsi ini dilakukan kegiatan-kegiatan penelitian dan pengembangan dilaksanakan sesuai dengan agendaagenda penelitian dan pengembangan yang telah ditemukan oleh kegiatan sesuai dengan fungsi alokasi.

c. Fungsi Komunikasi, fungsi ini dapat dilaksanakan jika analisis kebijaksanaan telah menghasilkan berbagai gagasan atau usulan kebijakan yang benar-benar realistis. Tugas para analisis kebijakan dalam hal ini ialah menyampaikan alternatif atau gagasan kebijakan tersebut kepada semua pihak yang berhubungan agar diperoleh suatu umpan balik mengenai keabsahan gagasan-gagasan yang diusulkan. Dalam fungsi komunikasi pertama yang perlu diperhatikan adalah, komunikasi dengan para pembuat kepu- 
tusan. Ini bertujuan untuk menyampaikan usul alternatif kebijakan kepada para pembuat keputusan sekaligus meyakinkan mereka bahwa alternatif kebijakan tersebut cukup realistis. Komunikasi kedua adalah komunikasi dengan para perencana dan pengelola dalam pelaksanaan kebijakan. Komunikasi dengan pihak-pihak tersebut dimaksudkan untuk meyakinkan mereka bahwa alternatif kebijakan ini sudah diuji apakah realistis atau tidak. Komunikasi ketiga adalah komunikasi dengan para pelaksana kebijakan diperlukan agar pihak-pihak yang melaksanakan setiap satuan kegiatan di lapangan mengetahui tujuan utama dari mereka yang lakukan. Komunikasi keempat yaitu komunikasi dengan masyarakat luas juga mutlak diperlukan dengan dasar pemikiran bahwa para pemimpin bangsa yang sekaligus merupakan para pembuat keputusan adalah para pelaksana dari aspirasi masyarakat luas. ${ }^{9}$

4. Proses kebijaksanaan

Proses analisis kebijakan adalah serangkaian aktivitas intelektual yang dilakukan di dalam proses kegiatan yang pada dasarnya bersifat politis. Aktivitas politis tersebut di jelaskan sebagai proses pembuatan kebijakan dan divisualisasikan sebagai serangkaian tahap yang saling bergantung yang diatur menurut urutan waktu: penyusunan agenda, formulasi kebijakan, adopsi kebijakan, implementasi kebijakan, dan penilaian kebijakan. ${ }^{10}$

a. Penyusunan Agenda

Agenda setting adalah sebuah fase dan proses yang sangat strategis dalam realitas kebijakan publik. Dalam proses inilah memiliki ruang untuk memaknai apa yang disebut sebagai masalah publik dan prioritas dalam agenda publik dipertarungkan. Jika sebuah isu berhasil mendapatkan status sebagai masalah publik, dan mendapatkan prioritas dalam agenda publik, maka isu tersebut berhak mendapatkan alokasi sumber daya publik yang lebih daripada isu lain.

${ }^{9}$ Ace Suryadi \& H.A.R Tilaar, Analisis Kebijakan Pendidikan Suatu Pengantar, (Bandung: Remaja Rosdakarya, 1993). Hlm. 56-69.

${ }^{10}$ William N Dunn, Pengantar Analisis ...,hlm. 120 
Dalam agenda setting juga sangat penting untuk menentukan suatu isu publik yang akan diangkat dalam suatu agenda lembaga pendidikan. Issue kebijakan (policy issues) sering disebut juga sebagai masalah kebijakan (policy problem). Policy issues biasanya muncul karena telah terjadi silang pendapat di antara para aktor mengenai arah tindakan yang telah atau akan ditempuh, atau pertentangan pandangan mengenai karakter permasalahan tersebut. Menurut William Dunn (2000), isu kebijakan merupakan produk atau fungsi dari adanya perdebatan baik tentang rumusan, rincian, penjelasan maupun penilaian atas suatu masalah tertentu. Namun tidak semua isu bisa masuk menjadi suatu agenda kebijakan.

Ada beberapa Kriteria isu yang bisa dijadikan agenda kebijakan publik di antaranya: 1) telah mencapai titik kritis tertentu jika diabaikan, akan menjadi ancaman yang serius; 2) telah mencapai tingkat partikularitas tertentu berdampak dramatis; 3) menyangkut emosi tertentu dari sudut kepentingan orang banyak (umat manusia) dan mendapat dukungan media massa; 4) menjangkau dampak yang amat luas; 5) mempermasalahkan kekuasaan dan keabsahan dalam masyarakat; 6) menyangkut suatu persoalan yang fasionable (sulit dijelaskan, tetapi mudah dirasakan kehadirannya). ${ }^{11}$

b. Formulasi kebijakan

Masalah yang sudah masuk dalam agenda kebijakan kemudian dibahas oleh para pembuat kebijakan. Masalah-masalah tadi didefinisikan untuk kemudian dicari pemecahan masalah yang terbaik. Pemecahan masalah tersebut berasal dari berbagai alternatif atau pilihan kebijakan yang ada. Sama halnya dengan perjuangan suatu masalah untuk masuk dalam agenda kebijakan, dalam tahap perumusan kebijakan masingmasing alternatif bersaing untuk dapat dipilih sebagai kebijakan yang diambil untuk memecahkan masalah.

${ }^{11}$ Sucipto , Analisis Kebijakan Pendidikan suatu Pengantar, (Jakarta: Bumi Aksara, 1987), hlm. 17. 
c. Adopsi/ Legitimasi Kebijakan

Tujuan legitimasi adalah untuk memberikan otorisasi pada proses dasar pemerintahan. Jika tindakan legitimasi dalam suatu masyarakat diatur oleh kedaulatan rakyat, warga negara akan mengikuti arahan pemerintah. Namun warga negara harus percaya bahwa tindakan pemerintah yang sah mendukung. Dukungan untuk rezim cenderung berdifusi-cadangan dari sikap baik dan niat baik terhadap tindakan pemerintah yang membantu anggota mentolerir pemerintahan disonansi. Legitimasi dapat dikelola melalui manipulasi simbol-simbol tertentu, di mana melalui proses ini orang belajar untuk mendukung pemerintah.

d. Evaluasi Kebijakan

Secara umum evaluasi kebijakan dapat dikatakan sebagai kegiatan yang menyangkut estimasi atau penilaian kebijakan yang mencakup substansi, implementasi dan dampak. Dalam hal ini, evaluasi dipandang sebagai suatu kegiatan fungsional. Artinya, evaluasi kebijakan tidak hanya dilakukan pada tahap akhir saja, melainkan dilakukan dalam seluruh proses kebijakan. Dengan demikian, evaluasi kebijakan bisa meliputi tahap perumusan masalah-masalah kebijakan, program-program yang diusulkan untuk menyelesaikan masalah kebijakan, implementasi, maupun tahap dampak kebijakan.

Dari pengertian terminologis tersebut kiranya jelas, bahwa analisis implementasi kebijakan adalah cara atau prosedur dalam menggunakan pemahaman manusia terhadap dan untuk memecahkan masalah dengan melibatkan hasil pengetahuan tentang proses kebijakan. Secara historis tujuan analisis kebijakan adalah menyediakan informasi bagi pembuat kebijakan untuk disajikan bahan pertimbangan yang nalar guna menemukan pemecahan masalah kebijakan. ${ }^{12}$

Dari beberapa tokoh di atas dapat disimpulkan bahwa "analisis implementasi kebijakan pembelajaran terpadu adalah cara atau prosedur secara intelektual dan

12 William N Dunn, Pengantar Analisis ...,hlm. 87. 
praktis yang ditujukan untuk menciptakan, secara kritis, menilai, dan mengomunikasikan pengetahuan ke dalam proses kebijakan pendidikan dalam pembelajaran terpadu.

Analisis implementasi kebijakan pembelajaran terpadu terhadap minat konsumen, ini juga tidak terlepas dari hasil tinjauan tentang apakah kualitas servis yang diberikan kepada konsumen mampu memuaskan pelanggan, apakah pelayanan yang terbaik untuk pelanggan sudah membudaya, apakah pelayanan yang diberikan melebihi pesaing, apakah jaminan yang di berikan terbukti dengan baik ketika mereka menggunakan, dan fungsional sesuai selera pasar.

\section{Konsep Pendidikan Islam Pada Sekolah Islam Terpadu}

Sekolah Islam terpadu pada hakikatnya adalah sekolah yang mengimplementasikan konsep pendidikan Islam berlandaskan AlQur'an dan As Sunnah. Dalam aplikasinya sekolah Islam terpadu diartikan sebagai sekolah yang menerapkan pendekatan penyelenggaraan dengan memadukan pendidikan umum dan pendidikan agama menjadi suatu jalinan kurikulum. Sekolah Islam terpadu juga menekankan keterpaduan dalam metode pembelajaran sehingga dapat mengoptimalkan ranah kognitif, afektif dan kognitif. Sekolah Islam terpadu juga memadukan pendidikan aqliyah, ruhiyah dan jasadiyah. Dalam penyelenggaraannya memadukan keterlibatan dan partisipasi aktif lingkungan belajar yaitu sekolah, rumah dan masyarakat.

Dengan sejumlah pengertian di atas dapat ditarik suatu pengetian umum yang komprehensif bahwa sekolah Islam terpadu adalah sekolah Islam yang diselenggarakan dengan memadukan secara integratif nilai dan ajaran Islam dalam bangunan kurikulum dengan pendekatan pembelajaran yang efektif dan pelibatan yang optimal dan koperatif antara guru dan orang tua, serta masyarakat untuk membina karakter dan kompetisi murid. ${ }^{13}$

Sekolah Islam Terpadu yang muncul sebagai alternatif solusi dari keresahan sebagian masyarakat muslim yang menginginkan adanya sebuah institusi pendidikan Islam yang berkomitmen

13 Moh. Uzer Usman, Menjadi Guru yang Profesioanal, (Bandung: Remaja Rosdakarya, 2008), hlm. 45. 
mengamalkan nilai-nilai Islam dalam sistemnya, dan bertujuan agar siswanya mempunyai kompetensi seimbang antara ilmu kauniyah dengan ilmu qauliyah, antara fikriyah, Ruhiyyah dan Jasadiyyah, sehingga mampu melahirkan generasi muda muslim yang berilmu, berwawasan luas dan bermanfaat bagi ummat. Dengan tujuan menciptakan siswa yang memiliki kecerdasan Intelektual (Intellegence Quotient/IQ), kecerdasan emosional (Emotional Quotient/EQ) dan kecerdasan spritual (Spritual Quotient/SQ) yang tinggi serta kemampuan beramal (kerja) yang ihsan. ${ }^{14}$

\section{Karakteristik Sekolah Islam Terpadu}

Dengan pengertian sebagaimana diuraikan di atas, maka sekolah Islam terpadu memiliki karakteristik di antaranya:

1. Menjadikan Islam sebagai landasan filosofis.

2. Mengintegrasikan nilai Islam ke dalam bangunan kurikulum.

3. Menerapkan dan mengembangkan metode pembelajaran untuk mengoptimalisasi proses belajar mengajar.

4. Mengedepankan uswah hasanah dalam membentuk karakter peserta didik.

5. Menumbuhkan kemaslahatan dan meniadakan kemaksiatan dan kemungkaran.

6. Melibatkan peran serta orang tua dan masyarakat dalam mendukung tercapainya tujuan pendidikan.

7. Mengutamakan nilai ukhuwah dalam semua interaksi antar warga sekolah.

8. Membangun budaya rawat, resik, runut, rapi, sehat dan asri.

9. Menjamin seluruh proses kegiatan sekolah untuk selalu berorientasi pada mutu.

${ }^{14}$ Mungin Eddy Wibowo, Pengembangan IQ, EQ, MQ, dan SQ dalam Proses Pembelajaran Pendidikan Di Era Otonomi Daerah dalam Abad 21, Makalah disajikan dalam seminar regional pada tanggal 3 November 2001 Himpunan Mahasiswa PJKR bekerja sama dengan BEM dan Unit Pelayanan Bimbingan dan konseling UNNES. 
10. Menumbuhkan budaya profesionalisme yang tinggi di kalangan tenaga pendidik dan tenaga kependidikan. ${ }^{15}$

Kesepuluh ciri atau karakteristik tersebut menjadi acuan bagi sekolah Islam terpadu dan oleh pengurus Jaringan Sekolah Islam Terpadu (JSIT) merupakan suatu gerakan da'wah berbasis pendidikan.

\section{E. Tujuan dan Penerapan Pendidikan Sekolah Islam Terpadu}

Sebagaimana yang disampaikan oleh Primarnie dan Armie dalam buku "Sekolah Islam Terpadu (Konsep dan Aplikasinya)", tujuan umum pendidikan sekolah Islam terpadu adalah membina peserta didik untuk menjadi insan muttaqien yang cerdas, berakhlak mulia dan memiliki keterampilan yang memberi manfaat dan maslahat bagi umat manusia. ${ }^{16}$

Membangun suatu sistem pendidikan yang baik berarti menyelenggarakan kegiatan pendidikan yang mampu membentuk kepribadian peserta didik. Kepribadian seseorang itu ditentukan oleh kualitas dan kuantitas pengalaman belajarnya, dengan demikian kegiatan pendidikan yang baik menuntut konsekuensi agar terbentuk lingkungan belajar yang kondusif. Arena (area) belajar yang baik secara sengaja direkayasa sedemikian rupa sehingga dapat membentuk pengetahuan, sikap keterampilan yang ditargetkan. Untuk membangun sekolah yang menggairahkan, maka seluruh proses kegiatan belajar mengajar mestilah dibangun dalam enam konsep umum yaitu rabbaniyah, integratif, stimulatif, fasilitatif, inovatif dan motivasi. Lingkungan belajar yang motivasi juga harus memunculkan iklim sekolah yang sehat yang ditandai dengan pola interaksi dan pergaulan yang hangat bersahabat antara seluruh tenaga pendidik dengan anak didik tanpa kehilangan dan kewibawaan mereka. ${ }^{17}$

15 Armie Primarnie. Membangun kerangka pendidikan Islam menuju konsep pendidikan monokotomik holistic. (Jakarta: Seri Kajian Pendidikan Islam, 2005), hlm. 54

${ }^{16}$ Primarnie. Sekolah Islam Terpadu (Konsep dan Aplikasinya), (Jakarta: JSIT Indonesia, 2006), hlm. 43-44.

${ }^{17}$ Rachmat Syarifudin. "Jaringan Sekolah Islam Terpadi (JSIT) Memberdayakan Sekolah-Sekolah Islam” copyright@2007 www.republika.com. 


\section{F. Pembelajaran Terpadu}

Sesuai dengan tahapan perkembangan anak, karakteristik cara anak belajar, konsep belajar dan pembelajaran bermakna, maka kegiatan pembelajaran bagi anak kelas awal SD sebaiknya dilakukan dengan Pembelajaran terpadu. Pembelajaran terpadu merupakan suatu pendekatan dalam pembelajaran yang secara sengaja mengaitkan beberapa aspek baik dalam mata pelajaran maupun antar mata pelajaran baik umum ataupun agama. Dengan adanya pemaduan itu siswa akan memperoleh pengetahuan dan keterampilan secara utuh sehingga pembelajaran menjadi bermakna bagi siswa. Bermakna di sini memberikan arti bahwa pada pembelajaran terpadu siswa akan dapat memahami konsepkonsep yang mereka pelajari melalui pengalaman langsung dan nyata yang menghubungkan antar konsep dalam mata pelajaran maupun antar mata pelajaran. Jika dibandingkan dengan pendekatan konvensional, maka pembelajaran terpadu tampak lebih menekankan pada keterlibatan siswa dalam belajar, sehingga siswa aktif terlibat dalam proses pembelajaran untuk pembuatan keputusan. Hal ini sesuai dengan panduan $\mathrm{KBK}^{18}$

Depdiknas (2003) yang menyatakan bahwa pengalaman belajar siswa menempati posisi penting dalam usaha meningkatkan kualitas lulusan. Untuk itu guru dituntut harus mampu merancang dan melaksanakan program pengalaman belajar dengan tepat. Setiap siswa memerlukan bekal pengetahuan dan kecakapan agar dapat hidup di masyarakat dan bekal ini diharapkan diperoleh melalui pengalaman belajar di sekolah. Oleh sebab itu pengalaman belajar di sekolah sebisa mungkin memberikan bekal siswa dalam mencapai kecakapan untuk berkarya. Kecakapan ini disebut dengan kecakapan hidup yang cakupannya lebih luas dibanding hanya sekedar keterampilan.

1. Terpadu sains dan agama dalam Islam

Menurut Qardhawi (2003) Islam tidak mengenal adanya pertentangan antara sains dan agama. Sains dalam persepsi Islam adalah bagian dari ajaran agama dan Islam merupakan sains. Agama tidak dapat dibangun dengan hanya berpegang teguh pada emosi dan keyakinan serta dugaan subyektif, tetapi harus dibangun dengan pikiran dan penalaran rasional dengan

18 Mulyasa. Manajemen Berbasis Sekolah (Konsep, Strategi dan Implementasi,), (Bandung: Remaja Rosdakarya, 2002), hlm. 56. 
argumentasi yang obyektif. Menggunakan pemikiran Qardhawi di atas sebagai analog, peneliti mencoba membangun pandangan yang terbalik bahwa sains tidak dapat hanya berpegang teguh pada pemikiran dan penalaran rasional dengan argumentasi obyektif, tetapi harus berpegang juga pada emosi dan keyakinan yang kadang bersifat obyektif. Pemikiran tersebut mendorong kemungkinan berkembangnya pemahaman yang terpadu antara sains dan agama. Sains yang dipahami dan dimaknai berdasarkan norma-norma agama dan agama yang dipahami dan dimaknai berdasarkan 'temuantemuan ilmiah atau fakta-fakta empiris. ${ }^{19}$

2. Pola-pola terpadu dalam Islam

Pengembangan mengenai pembelajaran terpadu sains dan agama adalah cara-cara yang dengannya manusia (ilmuwan) bekerja untuk memperoleh pengetahuan tentang ayat-ayat (realitas), baik ayat kauniyah maupun qauliyah. Realitas kauniyah adalah penggelaran alam semesta dan realitas qauliyah adalah susunan kata-kata dalam wahyu. Kedua realitas itu merupakan obyek pengetahuan manusia. Metode pembelajaran terpadu sains dan agama berarti cara-cara kerja seorang ilmuwan dalam memperoleh atau mengembangkan sebuah pengetahuan terpadu sains dan agama. Kata kerja terpadu dapat bergerak dari wahyu menuju alam empirik atau alam empirik menuju wahyu.

\section{Minat Konsumen Pendidikan}

Apabila kita melihat lembaga pendidikan dari kacamata sebuah corporate, maka lembaga pendidikan ini adalah suatu organisasi produksi yang menghasilkan jasa pendidikan yang dibeli oleh para konsumen. Konsumen utamanya ialah para siswa, di samping itu masih banyak konsumen lain. Apabila produsen tidak mampu memasarkan hasil produksinya, dalam hal ini jasa pendidikan disebabkan karena mutunya tidak disenangi oleh konsumen, tidak memberikan nilai tambah bagi peningkatan pribadi individu, layanan tidak memuaskan, maka produksi jasa yang ditawarkan tidak akan laku. Akibatnya sekolah akan mundur peminatnya tidak ada, akhirnya sekolah itu ditutup. Pada hakikatnya konsep bisnis, berarti penekanan

19 Yusuf Al-Qardhawi, Islam dan Globalisasi Dunia, terj. dari buku AlMuslimun wa Al-Aulamah, (Jakarta: Pustaka Al-Kautsar, 2001), hlm. 35. 
pada efisiensi dan kreativitas meningkatkan produktivitas dan menjaga kualitas. Demikian pula konsep pemasaran intinya adalah memuaskan konsumen, dan bagaimana pimpinan sekolah mengetahui dan meneliti apa sebenarnya keinginan konsumen atau siswanya. Bisnis dan marketing bukan bekerja dengan iklan dan promosi yang mengelabui masyarakat tapi mendidik dan meyakinkan masyarakat ke arah yang benar dan percaya bahwa sekolah ini bermutu. Hal-hal ini yang belum kita pahami selama ini sehingga orang alergi terhadap konsep tersebut. ${ }^{20}$

Keputusan konsumen dalam melakukan pembelian suatu produk pendidikan sebenarnya merupakan kumpulan dari sejumlah keputusan. Keputusan yang diambil oleh konsumen dapat berasal dari atribut yang dimiliki oleh produk tersebut. Atribut tersebut dapat berupa program pembelajaran terpadu, harga, kualitas, pelayanan yang diberikan dan citra lembaga.

a. Pembelajaran Terpadu. Terpadu merupakan keterkaitan beberapa sistem dalam pendidikan yang dapat diterapkan, mulai dari visi-misi, kurikulum, manajemen dan jaringan pendidikan yang dapat mengembangkan dan memajukan lembaga pendidikan Islam secara baik. Konsep pendidikan terpadu menjelaskan bahwa iman dan sains merupakan karakteristik insani, di mana manusia mempunyai kecenderungan untuk menuju kearah kebenaran dan wujudwujud suci dan tidak dapat hidup tanpa menyucikan dan memuja sesuatu ini adalah kecenderungan iman yang merupakan fitrah manusia. Tetapi di lain pihak manusia selalu ingin dan memahami semesta alam, serta memiliki kemampuan untuk memandang masa lalu, sekarang dan masa mendatang (yang merupakan ciri khas sains).

b. Harga. Harga dijadikan pertimbangan oleh konsumen dalam melakukan pembelian. Menurut Basu Swasta dan Ibnu Sukotjo mendefinisikan harga sebagai jumlah uang atau ditambah barang kalau mungkin, yang dibutuhkan untuk mendapatkan sejumlah barang beserta pelayanannya. Dari definisi tersebut kita dapat mengetahui bahwa harga yang

${ }^{20}$ Buchari Alma dan Ratih Hurryati, Manajemen Corporate dan Strategi Pemasaran Jasa Pendidikan, (Fokus Pada Mutu dan Layanan Prima), (Bandung: Alfabeta 2008), hlm. 13. 
dibayarkan pembeli itu sudah termasuk pelayanan yang diberikan oleh penjual, bahkan penjual juga menginginkan sejumlah keuntungan dari harga tersebut. Jika konsumen memenuhi harga tersebut maka harga itu sudah tepat. Dalam penetapan harga lembaga pendidikan tidak bisa menetapkan harga untuk semua keadaan. Harga dapat ditentukan dengan melihat tujuan dari penetapan harga. Banyak lembaga pendidikan yang secara sadar atau terang - terangan dalam menetapkan harga tidak memperhatikan tujuan lembaga pendidikan sehingga dalam penetapan harga tidak terarah pada pencapaian organisasi pendidikan. ${ }^{21}$ Lembaga pendidikan harus mempertimbangkan berbagai faktor dalam penetapan kebijakan harga. Philip Kotler mengemukakan langkah - langkah menetapkan harga yaitu : memilih tujuan penetapan harga, menentukan permintaan konsumen pendidikan, memperkirakan biaya produksi pendidikan, menganalisa biaya, harga dan tawaran pesaing, memilih metode penetapan harga dan memilih harga akhir. $^{22}$

c. Kualitas. Quality dalam pendidikan ini mendapatkan perhatian serius dalam National Quality Servey. Hal ini menunjukkan bahwa total kualitas manajemen dan isu-isu mutu secara umum mengundang perhatian publik. Dalam beberapa tahun terakhir, isu tersebut semakin meningkat. Masyarakat dari semua sektor pendidikan sekarang telah menunjukkan minatnya. Beberapa institusi mulai mewujudkan filosofi TQM ke dalam praktek dalam dunia pendidikan. Kualitas merupakan kesesuaian atau kecocokan dengan spesifikasi standar yang berlaku, cocok bila digunakan serta dapat memuaskan keinginan akan pemenuhan kebutuhan dan penghargaan konsumen atau pelanggan dengan biaya yang kompetitif. ${ }^{23}$

d. Kemudahan mendapatkan pelayanan. Pelayanan adalah suatu kegiatan interaksi antara penerima layanan dan pem-

21 Basu Swastha \& Ibnu Sukoco, Pengantar Bisnis Modern edisi 3, (Yogyakarta: Liberty, 1999), hlm. 76.

22 Philip Kotler, Manajemen Pemasaran, Terjemahan Hendra Teguh, Ronny A, Rusli, Benjamin Molan, jilid 1 \& 2 edisi milenium, (Jakarta: Prenhalindo, 2002 ), hlm. 67.

${ }^{23}$ Basu Swastha \& Ibnu Sukoco, Pengantar Bisnis Modern, hlm. 179. 
beri layanan di mana harapannya penerima layanan menjadi puas. Konsumen pendidikan merasa puas, apabila mereka memperoleh pelayanan yang baik dan sesuai dengan apa yang mereka harapkan. Setelah proses layanan pembelajaran dilakukan, disini akan didapatkan hasil apakah konsumen akan puas atau tidak puas. Kepuasan konsumen terlihat dari pembelian kembali produk pendidikan. Atau bisa pula setelah melakukan pembelian konsumen merasa tidak puas karena produk tersebut tidak dapat memuaskan kebutuhan dan keinginannya. Untuk menentukan puas tidaknya pembeli dapat dilihat dari hubungan antara harapan konsumen dan kinerja yang dirasakan dari produk. Jika kinerja tersebut memenuhi harapan, konsumen merasa puas, jika tidak maka konsumen tidak puas. Di sini lembaga pendidikan dapat memperkecil ketidakpuasan dengan melakukan klaim produk melalui pemasaran iklan yang menampilkan kinerja produk dengan penuh keyakinan sehingga para pembeli merasa puas.

e. Citra lembaga. Citra yang baik dari suatu organisasi lembaga pendidikan, merupakan aset yang tidak ternilai, karena citra mempunyai suatu dampak pada persepsi konsumen dari komunikasi dan operasi organisasi dalam berbagai hal. Salah satu operasi organisasi yang vital adalah pelayanan kepada konsumen pendidikan tersebut. Pelayanan menjadi sangat penting, mengingat pelayanan berhubungan langsung dengan konsumen. Melalui pelayanan inilah suatu organisasi dapat membentuk citra dimata masyarakat dan sebaliknya masyarakat dapat menilai citra organisasi melalui bagaimana suatu pelayanan disampaikan ke konsumen. Citra menurut Groonroos, merupakan fungsi dari pengalaman dan juga harapan konsumen. Pengalaman buruk dalam pelayanan yang dialami konsumen bisa menyebabkan persepsi yang cenderung buruk atau negatif. Sedangkan pengalaman yang baik dan harapan yang terpenuhi dalam pelayanan akan menjadikan terbentuknya persepsi yang positif.

f. Kepuasan Layanan. Konsumen pendidikan merasa puas, apabila mereka memperoleh pelayanan yang baik dan sesuai dengan apa yang mereka harapkan. Setelah proses layanan pembelajaran dilakukan, di sini akan didapatkan 
hasil apakah konsumen akan puas atau tidak puas. Kepuasan konsumen terlihat dari pembelian kembali produk pendidikan. Atau bisa pula setelah melakukan pembelian konsumen merasa tidak puas karena produk tersebut tidak dapat memuaskan kebutuhan dan keinginannya. Untuk menentukan puas tidaknya pembeli dapat dilihat dari hubungan antara harapan konsumen dan kinerja yang dirasakan dari produk. Jika kinerja tersebut memenuhi harapan, konsumen merasa puas, jika tidak maka konsumen tidak puas. Di sini lembaga pendidikan dapat memperkecil ketidakpuasan dengan melakukan klaim produk melalui pemasaran iklan yang menampilkan kinerja produk dengan penuh keyakinan sehingga para pembeli merasa puas.

\section{G. Kesimpulan}

Berdasarkan analisis data dapat disimpulkan bahwa kebijakan pembelajaran terpadu dilatarbelakangi: (1) Adanya keprihatinan dengan sistem pendidikan yang berkembang pada saat itu, yaitu pendidikan agama dan umum, (2) Ideologi dari pemikiran para pendiri lembaga pendidikan yang berkeinginan untuk mendidik putra-putrinya oleh komunitas mereka sendiri, (3) berusaha memenuhi harapan orang tua yang menginginkan akan keseimbangan pengetahuan antara agama dan umum.

Penelitian ini menunjukkan proses analisis kebijakan merupakan serangkaian aktivitas intelektual yang dilakukan di dalam proses kegiatan yang pada dasarnya bersifat politis, dan proses kebijakan pembelajaran terpadu meliputi (1) penyusunan agenda, (2) formulasi kebijakan, (3) adopsi kebijakan, (4) implementasi kebijakan, dan (5) penilaian kebijakan

Selain itu keberhasilan kebijakan tidak terlepas dari : (1) komunikasi, kejelasan ukuran dan tujuan kebijakan perlu dikomunikasikan secara tepat dengan para pelaksana, (2) sumberdaya, sumberdaya manusia yang tidak memadahi (jumlah dan kemampuan) berakibat tidak dapat dilaksanakannya program secara sempurna karena mereka tidak bisa melakukan dengan baik, (3) sikap, jika implementor setuju dengan bagian-bagian isi dari kebijakan maka mereka akan melaksanakan dengan senang hati tetapi jika pandangan mereka berbeda dengan pembuat kebijakan maka proses implementasi akan mengalami banyak masalah. 
Penelitian ini juga menunjukkan bahwa motivasi orang tua menyekolahkan anaknya di dua lembaga tersebut dengan pertimbangan: (1) program pembelajaran terpadu, (2) kualitas lembaga pendidikan, (3) biayanya pendidikan, dan (4) citra lembaga yang baik .

\section{Kepustakaan}

Alma, Buchari dan Ratih Hurryati. 2008. Manajemen Corporate dan Strategi Pemasaran Jasa Pendidikan ( Fokus Pada Mutu dan Layanan Prima). Bandung: Alfabeta

Amir, Jusuf. 1995. Reorientasi Pendidikan Islam. Jakarta: Gema Insani Press

Anggoro, Linggar 2002. Teori dan Profesi Kehumasan. Jakarta: Bumi Aksara

Arifin, M. 1991. Kapita Selekta Pendidikan (Islam dan Umum). Jakarta: Bumi Aksara

Badan Penelitian dan Pengembangan Pusat Kurikulum. 2001. Kebijakan Umum Kurikulum Berbasis Kompetensi Pendidikan Dasar dan Menengah. Jakarta: Departemen Pendidikan Nasional.

Bogdan, Robert. C. dan Biklen, Sari Knopp. 1990. Riset Kualitatif Untuk Pendidikan: Pengantar Teori dan Metode. Alih Bahasa: Munandir. Jakarta: Ditjen Dikti Depdikbud.

Dunn, William N. 2000. Pengantar Analisis Kebijakan Publik. Yogyakarta: Gajah Mada University Press

Imron, Ali. 1996. Kebijakan Pendidikan di Indonesia (Proses, Produk, dan Masa Depannya). Jakarta: Bumi Aksara

Iriantara, Yosal. 2004. Community relations (konsep dan aplikasinya), Bandung: Remaja Rosdakarya. Jakarta: Bumi Aksara

Kotler, Philip. 2002. Manajemen Pemasaran, Terjemahan Hendra Teguh, Ronny A, Rusli, Benjamin Molan, jilid 1 \& 2 edisi milenium. Jakarta: Prenhalindo.

Kusumastuti. 2000. Dasar-dasar Humas. Jakarta: Ghalia Indonesia. 
Primarnie, Armie. 2005. Membangun kerangka pendidikan Islam menuju konsep pendidikan monokotomik holistic. Jakarta: Seri Kajian Pendidikan Islam.

Primarnie, Armie. 2006. Sekolah Islam Terpadu (Konsep dan Aplikasinya). Jakarta: JSIT Indonesia.Suharto, Edi. 2007. Kebijakan Sosial Sebagai Kebijakan Publik. Bandung: Alfabeta.

Swastha, Basu \& Hani Handoko. 1997. Manajemen Pemasaran : Analisis Perilaku Konsumen. Jakarta: BPFE.

Swastha, Basu \& Ibnu Sukoco. 1999. Pengantar Bisnis Modern edisi 3. Yogyakarta: Liberty.

Tjiptono, Fandy \& Anastasia Diana. 2003. Total Quality Management. Yogyakarta: Andi. 
